\title{
Mononuclear and Dinuclear Manganese(II) Complexes from the Use of Methyl(2-pyridyl)ketone Oxime
}

\section{Constantinos G. Efthymiou, ${ }^{1,2}$ Vassilios Nastopoulos, ${ }^{1}$ Catherine Raptopoulou, ${ }^{3}$ Anastasios Tasiopoulos, ${ }^{4}$ Spyros P. Perlepes, ${ }^{1}$ and Constantina Papatriantafyllopoulou ${ }^{2}$}

\author{
${ }^{1}$ Department of Chemistry, University of Patras, 26504 Patras, Greece \\ ${ }^{2}$ Department of Chemistry, University of Florida, Gainesville, FL 32611-7200, USA \\ ${ }^{3}$ Institute of Materials Science, National Centre of Scientific Research "Demokritos", 15310 Aghia Paraskevi Attikis, Greece \\ ${ }^{4}$ Department of Chemistry, University of Cyprus, 1678 Nicosia, Cyprus
}

Correspondence should be addressed to Constantina Papatriantafyllopoulou, cpapat@chem.ufl.edu

Received 23 March 2010; Accepted 3 May 2010

Academic Editor: Evy Manessi-Zoupa

Copyright (C 2010 Constantinos G. Efthymiou et al. This is an open access article distributed under the Creative Commons Attribution License, which permits unrestricted use, distribution, and reproduction in any medium, provided the original work is properly cited.

\begin{abstract}
The reactions of methyl(2-pyridyl)ketone oxime, (py) $\mathrm{C}(\mathrm{Me}) \mathrm{NOH}$, with manganese(II) sulfate monohydrate have been investigated. The reaction between equimolar quantities of $\mathrm{MnSO}_{4} \cdot \mathrm{H}_{2} \mathrm{O}$ and $(\mathrm{py}) \mathrm{C}(\mathrm{Me}) \mathrm{NOH}$ in $\mathrm{H}_{2} \mathrm{O}$ lead to the dinuclear complex $\left[\mathrm{Mn}_{2}\left(\mathrm{SO}_{4}\right)_{2}\{(\mathrm{py}) \mathrm{C}(\mathrm{Me}) \mathrm{NOH}\}_{4}\right] \cdot($ py $) \mathrm{C}(\mathrm{Me}) \mathrm{NOH}, \mathbf{1} \cdot(\mathrm{py}) \mathrm{C}(\mathrm{Me}) \mathrm{NOH}$, while employment of NaOMe as base affords the compound $\left[\mathrm{Mn}\left(\mathrm{HCO}_{2}\right)_{2}\{(\mathrm{py}) \mathrm{C}(\mathrm{Me}) \mathrm{NOH}\}_{2}\right](2)$. The structures of both compounds have been determined by single crystal $\mathrm{X}$-ray diffraction. In both complexes, the organic ligand chelates through its nitrogen atoms. The IR data are discussed in terms of the nature of bonding and the structures of the two complexes.
\end{abstract}

\section{Introduction}

There is currently a renewed interest in the coordination chemistry of oximes [1]. The research efforts are driven by a number of considerations. One of these is that they are considered to be reasonable models for the biologically significant imidazole donor group of the amino acid histidine [2]. Thus, they potentially can be used for the synthesis of various nuclearity metal clusters to model $\mathrm{M}_{\mathrm{x}}$ sites in biomolecules, including elucidating the structure and mechanism of action of the $\mathrm{CaMn}_{4}$ core of the water oxidizing complex within the photosynthetic apparatus of green plants and cyanobacteria $[3,4]$. In addition, metal complexes of oximes can be used in several other applications, that is, the solution of pure chemical problems $[5,6]$, the development of new oxygen activation catalysts based on nickel(II) polyoximate complexes [7] and the application of metal ion/oxime systems as efficient catalysts for the hydrolysis of organonitriles [8]. In the latter, metal ions can behave as extremely strong activators of RCN molecules towards nucleophilic attack by $\mathrm{OH}^{-} / \mathrm{H}_{2} \mathrm{O}$. Other applications of metal complexes of oximes include the design of $\mathrm{Ca}^{2+}$ - and $\mathrm{Ba}^{2+}$-selective receptors based on site-selective transmetallation of polynuclear zinc (II)/polyoxime complexes [9], the study of metal-ion assisted organic transformations [10], and the mechanistic investigation of corrosion inhibition by Acorga P5000 (a modern corrosion inhibitor comprising 5nonylsalicylaldoxime as a mixture of carbon-chain isomers) on iron surfaces [11]. Note also that oximate ligands are employed in the synthesis of homo- and heterometallic [1, 12] clusters and coordination polymers [13] with interesting magnetic properties, including single-molecule magnetism [14-16], and single-chain magnetism [17] behavior.

Ligands containing one oxime group and one pyridyl group, without other donor sites, are popular in coordination chemistry. Metal-free pyridine oximes exhibit a plethora of biological properties including action on the cardiovascular system, sedative, antidepressant, antispasmodic, cytotoxic, antiviral, and bactericidal activities, while they are good antidotes for poisoning by organophosphorus compounds [18]. Most of these ligands contain a 2-pyridyl group, and thus are named 2-pyridyl oximes, 
<smiles>[R]/C(=N/O)c1ccccn1</smiles>

$\mathrm{R}=\mathrm{H} ;($ py $) \mathrm{C}(\mathrm{H}) \mathrm{NOH}$

$\mathrm{R}=\mathrm{Me} ;(\mathrm{py}) \mathrm{C}(\mathrm{Me}) \mathrm{NOH}$

$\mathrm{R}=\mathrm{Ph} ;(\mathrm{py}) \mathrm{C}(\mathrm{ph}) \mathrm{NOH}$

$\mathrm{R}=\prod_{\mathrm{N}} ;(\mathrm{py})_{2} \mathrm{CNOH}$

Scheme 1: General structural formula and abbreviations of simple 2-pyridyl oximes, including methyl(2-pyridyl)ketone oxime $[(\mathrm{py}) \mathrm{C}(\mathrm{Me}) \mathrm{NOH}]$.

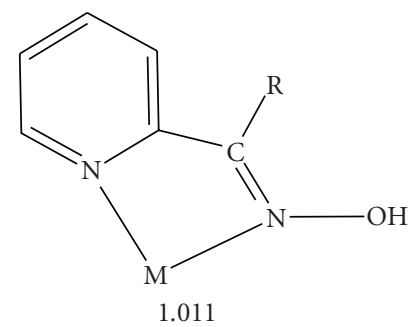

Scheme 2: The common coordination mode of the neutral 2pyridyl oximes and the Harris notation [26] which describes this mode.

(py)C(R)NOH (Scheme 1). The anionic forms of these molecules, (py) $\mathrm{C}(\mathrm{R}) \mathrm{NO}^{-}$, are versatile ligands for a variety of research objectives, including $\mu_{2}$ and $\mu_{3}$ behaviour; the activation of 2-pyridyl oximes by $3 \mathrm{~d}$-metal centers towards further reactions is also becoming a fruitful area of research. The majority of the metal complexes of these ligands have been prepared in the last 15 years and much of their chemistry remains to be explored in more detail [1].

With only few exceptions $[19,20]$, the hitherto structurally characterized metal complexes containing neutral 2pyridyl oximes as ligands are mononuclear. The donor atoms of the neutral 2-pyridyl oximes in metal complexes are the nitrogen atom of the oxime group and the nitrogen atom of the pyridyl group. Thus, (py) $\mathrm{C}(\mathrm{R}) \mathrm{NOH}$ behave as $N, N^{\prime}$-chelating ligands (see Scheme 2) making necessary the employment of additional inorganic or organic anions to complete the coordination sphere of the metal centre or to balance the charge of the complex cation. A variety of monoanions have been used for this reason, for example, $\mathrm{PhCO}_{2}{ }^{-}$[21], $\mathrm{Cl}^{-}$[22, 23], $\mathrm{Br}^{-}$[24], and $\mathrm{NO}_{3}{ }^{-}$[25]. Recently, we have started a research program to explore the use of the sulfate ion, $\mathrm{SO}_{4}{ }^{2-}$, in $3 \mathrm{~d}$-metal/2-pyridyl oxime chemistry, instead of the abovementioned monoanionic ligands. The possible advantages of using $\mathrm{SO}_{4}{ }^{2-}$ include (i) the possibility of triggering aggregation of preformed smaller species into new products, and (ii) the possible diversion of known reaction systems developed using inorganic monoanions to new species as a result of the higher charge and higher denticity of the sulfate ligand.

The sulfate ion [27] is currently a ligand of intense interest. The $\mu_{2}, \mu_{3}, \mu_{4}, \mu_{5}, \mu_{8}$, or $\mu_{10}$ potential of $\mathrm{SO}_{4}{ }^{2-}$ (Scheme 3) prompted as to combine 2-pyridyloximes with the sulfate ligand to aim at new types of compounds.
In this paper, we report the synthesis and the X-ray structural characterization of the two new $\mathrm{Mn}$ (II) complexes $\left[\mathrm{Mn}_{2}\left(\mathrm{SO}_{4}\right)_{2}\{(\mathrm{py}) \mathrm{C}(\mathrm{Me}) \mathrm{NOH}\}_{4}\right] \cdot(\mathrm{py}) \mathrm{C}(\mathrm{Me}) \mathrm{NOH}$

$(\mathbf{1} \cdot($ py $) \mathrm{C}(\mathrm{Me}) \mathrm{NOH})$ and $\left[\mathrm{Mn}\left(\mathrm{HCO}_{2}\right)_{2}\{(\mathrm{py}) \mathrm{C}(\mathrm{Me}) \mathrm{NOH}\}_{2}\right]$ (2) which contain the neutral methyl(2-pyridyl)ketone oxime as organic ligand. The IR data are discussed in terms of the nature of bonding and the structures of the two complexes.

\section{Experiments}

All manipulations were performed under aerobic conditions using materials and solvents as received. IR spectra were recorded on a Perkin-Elmer PC16 FT-IR spectrometer with samples prepared as $\mathrm{KBr}$ pellets.

$\left[\mathrm{Mn}_{2}\left(\mathrm{SO}_{4}\right)_{2}\left\{(\right.\right.$ py $\left.) \mathrm{C}(\mathrm{Me}) \mathrm{NOH}_{4}\right] \cdot($ py $) \mathrm{C}(\mathrm{Me}) \mathrm{NOH}(\mathbf{1}$. (py)C(Me)NOH). Solid $\mathrm{MnSO}_{4} \cdot \mathrm{H}_{2} \mathrm{O}(0.067 \mathrm{~g}, 0.40 \mathrm{mmol})$ was added to a slurry of (py) $\mathrm{C}(\mathrm{Me}) \mathrm{NOH} \quad(0.054 \mathrm{~g}$, $0.40 \mathrm{mmol})$ in $\mathrm{H}_{2} \mathrm{O}\left(15 \mathrm{~cm}^{3}\right)$; the solid soon dissolved and the solution was stirred for 1 hour at room temperature. The resultant solution was left for slow evaporation. After one week, yellow crystals appeared which were collected by filtration, washed with cold $\mathrm{H}_{2} \mathrm{O}\left(1 \mathrm{~cm}^{3}\right)$, cold $\mathrm{MeOH}$ $\left(1 \mathrm{~cm}^{3}\right)$ and ice-cold $\mathrm{Et}_{2} \mathrm{O}\left(2 \mathrm{~cm}^{3}\right)$, and dried in air. The yield was $79 \%$ (based on the metal). Found \%: C, 42.94; H, 3.89; $\mathrm{N}, 14.51$. Calc $\%$ for $\mathrm{C}_{35} \mathrm{H}_{40} \mathrm{O}_{13} \mathrm{~N}_{10} \mathrm{~S}_{2} \mathrm{Mn}_{2}$ : C, 42.78; $\mathrm{H}, 4.10$; and $\mathrm{N}, 14.25$. Selected IR data $\left(\mathrm{KBr}, \mathrm{cm}^{-1}\right): 3420(\mathrm{wb}), 3150$ (m), $3069(\mathrm{~m}), 2843(\mathrm{~m}), 2363(\mathrm{w}), 2343(\mathrm{w}), 1654(\mathrm{w}), 1593$ (s), $1561(\mathrm{~m}), 1476(\mathrm{~s}), 1437(\mathrm{~m}), 1327(\mathrm{~m}), 1285(\mathrm{w}), 1215$ (m), 1124 (s), 1080 (s), 1030 (s), 1010 (s), 989 (s), 781 (s), $748(\mathrm{~m}), 683(\mathrm{~m}), 631(\mathrm{~m}), 592(\mathrm{~m}), 561(\mathrm{w}), 494(\mathrm{w}), 452$ (w), and $447(\mathrm{w})$.

$\left[\mathrm{Mn}\left(\mathrm{HCO}_{2}\right)_{2}\left\{(p y) \mathrm{C}(\mathrm{Me}) \mathrm{NOH}_{2}\right]\right.$ (2). Solid $\mathrm{NaOMe}(0.090 \mathrm{~g}$, $1.50 \mathrm{mmol})$ was added to a colourless solution of (py)C(Me) $\mathrm{NOH}(0.204 \mathrm{~g}, 1.50 \mathrm{mmol})$ in $\mathrm{CH}_{2} \mathrm{Cl}_{2}\left(20 \mathrm{~cm}^{3}\right)$; the solid soon dissolved. Solid $\mathrm{MnSO}_{4} \cdot \mathrm{H}_{2} \mathrm{O}(0.250 \mathrm{~g}$, $1.50 \mathrm{mmol}$ ) was then added and the resulting solution was stirred for 24 hours at room temperature. A small quantity of undissolved material was removed by filtration and the dark brown filtrate layered with $\mathrm{Et}_{2} \mathrm{O}\left(40 \mathrm{~cm}^{3}\right)$. Slow mixing gave $\mathrm{X}$-ray quality yellow crystals of the product. The crystals were collected by filtration, washed with cold $\mathrm{H}_{2} \mathrm{O}\left(1 \mathrm{~cm}^{3}\right)$, cold $\mathrm{MeOH}\left(2 \mathrm{~cm}^{3}\right)$, and ice-cold $\mathrm{Et}_{2} \mathrm{O}\left(2 \times 3 \mathrm{~cm}^{3}\right)$, and dried in air. The yield was $45 \%$ (based on the metal). Found \%: C, 46.95; $\mathrm{H}, 4.26 ; \mathrm{N}, 13.43$. Calc \% for $\mathrm{C}_{16} \mathrm{H}_{18} \mathrm{O}_{6} \mathrm{~N}_{4} \mathrm{Mn}$ : C, 46.82; H, 4.13; N, 13.98. Selected IR data $\left(\mathrm{KBr}, \mathrm{cm}^{-1}\right)$ : $3412(\mathrm{mb}), 3073(\mathrm{w}), 2362(\mathrm{~m}), 1846(\mathrm{~m}), 1597(\mathrm{~s}), 1562(\mathrm{~s})$, 1475 (s), $1436(\mathrm{~m}), 1365$ (s), $1348(\mathrm{~s}), 1326(\mathrm{~m}), 1250(\mathrm{w})$, $1165(\mathrm{w}), 1137(\mathrm{~m}), 1042(\mathrm{~s}), 961(\mathrm{~m}), 782(\mathrm{~s}), 751(\mathrm{~s}), 683$ (m), $562(\mathrm{w})$, and $458(\mathrm{w})$.

2.1. X-Ray Crystallography. For $\mathbf{1} \cdot(\mathrm{py}) \mathrm{C}(\mathrm{Me}) \mathrm{NOH}, \mathrm{X}$-Ray data were collected at $298 \mathrm{~K}$ using a Crystal Logic Dual Goniometer diffractometer with graphite-monochromated Mo- $K_{a}$ radiation $(\lambda=0.71073 \AA)$. Lorentz, polarization, and $\Psi$-scan absorption corrections were applied using Crystal Logic software. Symmetry equivalent data were averaged 
<smiles>[M]O[Sb](O)(O)O</smiles>

1.1<smiles>[M]O[Sb]1(O[M])O[M]O1</smiles>

2.1111<smiles>[M]O[Sb](O)(O)O[M]</smiles>

3.21<smiles>[M]O[SH](O)(O[M])O[M]</smiles>

4.22<smiles>[M]OS(O[M])(O[M])O[M]</smiles>

5.2211<smiles>[M]O[SH](O[M])[Si](O[M])(O[M])O[M]</smiles>

8.2222<smiles>[M]O[Sb](O)(O)O[M]</smiles>

2.11<smiles>[M]O[Sb](O)(O[M])O[M]</smiles>

2.111<smiles>[M]OS(O[M])(O[M])O[M]</smiles>

4.1111<smiles>[M]OS(O[M])(O[M])O[M]</smiles>

5.221<smiles>[M]O[Si](O[M])(O[M])S([M])([M])O[M]</smiles>

10.3322<smiles>[M]O[Sb](O)(O)(O)O[M]</smiles>

2.2

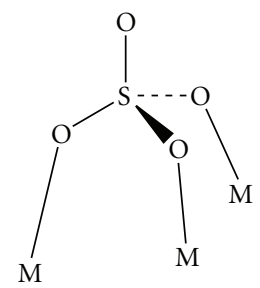

3.111<smiles>[M]OS(O[M])(O[M])O[M]</smiles>

4.221

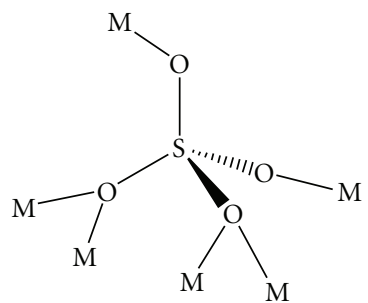

6.2211

Scheme 3: The up to now crystallographically established coordination modes of the sulfato ligand and the Harris notation [26] which describes these modes. 
with $R_{\text {int }}=0.0084$, to give 3727 independent reflections from a total 3964 collected. The structure was solved by direct methods and refined by full-matrix least-squares on $\mathrm{F}^{2}$, using 3727 reflections and refining 325 parameters. All nonhydrogen atoms were refined anisotropically. Hydrogen atoms were either located by difference maps and were refined isotropically or were introduced at calculated positions as riding on bonded atoms.

For 2, X-ray data were collected at $100 \mathrm{~K}$ using a Oxford Diffraction diffractometer with graphite-monochromated Mo- $K_{a}$ radiation $(\lambda=0.71073 \AA)$. Symmetry equivalent data were averaged with $R_{\text {int }}=0.0160$, to give 9343 independent reflections from a total of 13039 collected. The structure was solved by direct methods and refined by full-matrix leastsquares on $\mathrm{F}^{2}$, using 9343 reflections and refining 258 parameters. All non-hydrogen atoms were refined anisotropically. Hydrogen atoms were either located by difference maps and were refined isotropically or were introduced at calculated positions as riding on bonded atoms.

Details of the data collection and refinement for $\mathbf{1} \cdot($ py) $\mathrm{C}(\mathrm{Me}) \mathrm{NOH}$ and 2 are given in Table 1.

\section{Results and Discussion}

3.1. Synthetic Comments. Treatment of $\mathrm{MnSO}_{4} \cdot \mathrm{H}_{2} \mathrm{O}$ with one equivalent of (py)C(Me)NOH in $\mathrm{H}_{2} \mathrm{O}$ gave a colorless solution from which the new dinuclear compound $\left[\mathrm{Mn}_{2}\left(\mathrm{SO}_{4}\right)_{2}\{(\text { py }) \mathrm{C}(\mathrm{Me}) \mathrm{NOH}\}_{4}\right] \cdot($ py $) \mathrm{C}(\mathrm{Me}) \mathrm{NOH}$

(1. (py)C(Me)NOH) was obtained in $\sim 80 \%$ yield. Its formation can be summarized in (1).

$$
\begin{aligned}
& 2 \mathrm{MnSO}_{4} \cdot \mathrm{H}_{2} \mathrm{O}+5(\text { py }) \mathrm{C}(\mathrm{Me}) \mathrm{NOH} \\
& \stackrel{\mathrm{H}_{2} \mathrm{O}}{\longrightarrow}\left[\mathrm{Mn}_{2}\left(\mathrm{SO}_{4}\right)_{2}\left\{(\mathrm{py}) \mathrm{C}(\mathrm{Me}) \mathrm{NOH}_{4}\right]\right. \\
& \cdot(\mathrm{py}) \mathrm{C}(\mathrm{Me}) \mathrm{NOH}+2 \mathrm{H}_{2} \mathrm{O} \\
& 1 \cdot(\mathrm{py}) \mathrm{C}(\mathrm{Me}) \mathrm{NOH} .
\end{aligned}
$$

The nonstoichiometric $\mathrm{MnSO}_{4} \cdot \mathrm{H}_{2} \mathrm{O}$ to (py) $\mathrm{C}(\mathrm{Me}) \mathrm{NOH}$ reaction ratio $(1: 1)$ employed for the preparation of 1. (py)C(Me)NOH (Section 2) did not prove detrimental to the formation of the complex. With the identity of $\mathbf{1} \cdot(\mathrm{py}) \mathrm{C}(\mathrm{Me}) \mathrm{NOH}$ established by single-crystal X-ray crystallography, the "correct" stoichiometry $(1: 2.5)$ was employed and led to the pure compound in high yield.

As a next step, we decided to add base in the reaction mixture targeting the deprotonation of the organic ligand. Thus, treatment of $\mathrm{MnSO}_{4} \cdot \mathrm{H}_{2} \mathrm{O}$ with one equivalent of (py) $\mathrm{C}(\mathrm{Me}) \mathrm{NOH}$ and one equivalent of $\mathrm{NaOMe}$ in $\mathrm{CH}_{2} \mathrm{Cl}_{2}$ gave a dark brown solution from which the mononuclear compound $\left[\mathrm{Mn}\left(\mathrm{HCO}_{2}\right)_{2}\left\{(\mathrm{py}) \mathrm{C}(\mathrm{Me}) \mathrm{NOH}_{2}\right]\right.$ (2) was obtained. Its formation can be summarized in(2)

$$
\begin{aligned}
& \mathrm{MnSO}_{4} \cdot \mathrm{H}_{2} \mathrm{O}+2(\text { py }) \mathrm{C}(\mathrm{Me}) \mathrm{NOH}+2 \mathrm{NaOMe}+2 \mathrm{O}_{2} \\
& \stackrel{\mathrm{CH}_{2} \mathrm{Cl}_{2}}{\longrightarrow}\left[\mathrm{Mn}\left(\mathrm{HCO}_{2}\right)_{2}\{(\text { py }) \mathrm{C}(\mathrm{Me}) \mathrm{NOH}\}_{2}\right] \\
& +\mathrm{Na}_{2} \mathrm{SO}_{4}+3 \mathrm{H}_{2} \mathrm{O} .
\end{aligned}
$$

To our surprise, an amount of the methoxide ions did not act as proton acceptors but they got oxidized to formates $\left(\mathrm{HCO}_{2}^{-}\right)$during the aerial aggregation process [28]. Thus, the organic ligand in 2 is neutral. As expected, the nature of the base is crucial for the identity of the product; employment of $\mathrm{NEt}_{3}, \mathrm{NMe}_{4} \mathrm{OH}, \mathrm{NEt}_{4} \mathrm{OH}, \mathrm{LiOH} \cdot \mathrm{H}_{2} \mathrm{O}$ etc. leads to dark brown oily materials that have not been characterized. Also, note that: (i) The color of $\mathbf{2}$ (yellow) is different than the color of the reaction mixture (dark brown, this colour is characteristic of $\mathrm{Mn}^{\mathrm{III}}$ or $\mathrm{Mn}^{\mathrm{II} / \mathrm{III}}$ species), and (ii) a similar reaction, but with (py) $\mathrm{C}(\mathrm{ph}) \mathrm{NOH}$ instead of (py) $\mathrm{C}(\mathrm{Me}) \mathrm{NOH}$, yields the octanuclear mixed-valent cluster $\left[\mathrm{Mn}_{4}{ }_{4} \mathrm{Mn}_{4}{ }_{4} \mathrm{O}_{4}\left(\mathrm{NO}_{3}\right)_{2}\left\{(\mathrm{py}) \mathrm{C}(\mathrm{ph}) \mathrm{NO}_{8}(\mathrm{HCOO})_{2}\right.\right.$ $(\mathrm{MeOH})_{2}$ ] [29] whose core consists of two butterfly subunits. These observations indicate that compound 2 is not the only product of the reaction and that, presumably, a higher nuclearity cluster, with the metals at higher oxidation states, is present in solution. Work is in progress to isolate the second product from the reaction mixture.

3.2. Description of Structures. Selected interatomic distances and angles for complexes $\mathbf{1} \cdot(\mathrm{py}) \mathrm{C}(\mathrm{Me}) \mathrm{NOH}$ and $\mathbf{2}$ are listed in Tables 2 and 4, respectively. The molecular structures of the two compounds are shown in Figures 1 and 2.

Complex $\mathbf{1} \cdot(\mathrm{py}) \mathrm{C}(\mathrm{Me}) \mathrm{NOH}$ crystallizes in the triclinic space group $P-1$. Its structure consists of dinuclear $\left[\mathrm{Mn}_{2}\left(\mathrm{SO}_{4}\right)_{2}\{(\mathrm{py}) \mathrm{C}(\mathrm{Me}) \mathrm{NOH}\}_{4}\right]$ molecules and (py)C(Me)NOH molecules in the crystal lattice. The dinuclear molecules lie on a crystallographic inversion center. The two $\mathrm{Mn}^{\mathrm{II}}$ atoms are bridged by two $\eta^{1}: \eta^{1}: \mu_{2}$ or 2.1100 (Harris notation [26]) sulfato ligands; two $N, N$ '-chelating (py)C(Me) $\mathrm{NOH}$ ligands complete six coordination at each metal center. The ligating atoms of (py) $\mathrm{C}(\mathrm{Me}) \mathrm{NOH}$ are the nitrogen atoms of the neutral oxime and 2-pyridyl groups. Thus, adopting the Harris notation, (py) $\mathrm{C}(\mathrm{Me}) \mathrm{NOH}$ behaves as an 1.011 ligand.

The coordination sphere of the $\mathrm{Mn}^{\mathrm{II}}$ ion in 1.(py)C(Me) $\mathrm{NOH}$ exhibits a slightly distorted octahedral geometry as a consequence of the relatively small bite angles of the chelating ligands [N1-Mn-N2=70.11(10), $\mathrm{N} 11-\mathrm{Mn}-\mathrm{N} 12=70.19(10)^{\circ} \mathrm{]}$. Both sulfato oxygen atoms $\mathrm{O}(31)$ and $\mathrm{O}\left(32^{\prime}\right)$ are trans to the pyridyl nitrogen atoms $\mathrm{N}(1)$ and $\mathrm{N}(11)$, respectively. Each metal center adopts the cis-cis-trans configuration considering the position of the coordinated $\mathrm{SO}_{4}{ }^{2-}$ oxygen, pyridyl nitrogen and oxime nitrogen atoms, respectively. The cis arrangement of the oxime groups seems unfavourable, probably due to the steric hindrance arising from the methyl group upon oxime coordination. The long Mn $\cdots \mathrm{Mn}^{\prime}$ distance [5.040(2) $\AA$ ] is a consequence of the presence of the two syn, anti sulfato bridges.

The molecular structure of $\mathbf{1} \cdot(\mathrm{py}) \mathrm{C}(\mathrm{Me}) \mathrm{NOH}$ is stabilized by intramolecular hydrogen bonds (Table 3 ). Each coordinated (py) $\mathrm{C}(\mathrm{Me}) \mathrm{NOH}$ oxime group is strongly hydrogen bonded to an uncoordinated $\mathrm{O}$ atom of the sulfato ligand (O33 or $\mathrm{O} 33^{\prime}$ ). Thus, O33 (and its symmetry equivalent) participates in two hydrogen bonds. 
TABle 1: Crystal data and structure refinement for $\mathbf{1} \cdot($ py) $\mathrm{C}(\mathrm{Me}) \mathrm{NOH}$ and 2.

\begin{tabular}{lcc}
\hline Empirical formula & $\mathrm{C}_{35} \mathrm{H}_{40} \mathrm{Mn}_{2} \mathrm{~N}_{10} \mathrm{O}_{13} \mathrm{~S}_{2}$ & $\mathrm{C}_{16} \mathrm{H}_{18} \mathrm{MnN}_{4} \mathrm{O}_{6}$ \\
\hline Formula weight & 982.77 & 417.28 \\
Crystal size & $0.75 \times 0.50 \times 0.40$ & $0.25 \times 0.20 \times 0.20$ \\
Crystal system & triclinic & $\mathrm{monoclinic}$ \\
Space group & $\mathrm{P}-1$ & $\mathrm{P}{ }_{1} / \mathrm{n}$ \\
$\theta$ range for data collection. & $5.4 \leq \theta \leq 30.1$ \\
$a, \AA$ & $5.5 \leq 11.0$ & $10.6538(5)$ \\
$b, \AA$ & $9.627(4)$ & $14.3935(7)$ \\
$c, \AA$ & $9.962(4)$ & $11.8231(8)$ \\
$\alpha,{ }^{\circ}$ & $11.750(4)$ & 90.00 \\
$\beta,{ }^{\circ}$ & $92.610(10)$ & $90.264(7)$ \\
$\gamma,{ }^{\circ}$ & $96.560(10)$ & 90.00 \\
$V, \AA^{3}$ & $107.450(10)$ & $1813.00(17)$ \\
$Z$ & $1064.2(7)$ & 4 \\
$\rho_{\text {calcd }}$, gcm $^{-3}$ & 1 & 1.529 \\
$\mu, \mathrm{mm}^{-1}$ & 1.534 & 0.770 \\
$G O F$ & 0.766 & 1.009 \\
$R 1^{\mathrm{a}}$ & 1.116 & 0.0344 \\
$w R 2^{\mathrm{b}}$ & 0.0443 & 0.0948 \\
\hline
\end{tabular}

${ }^{\mathrm{a}} I>2 \sigma(I), R_{1}=\sum\left(\left|F_{\mathrm{o}}\right|-\left|F_{\mathrm{c}}\right|\right) / \sum\left(\left|F_{\mathrm{o}}\right|\right)$

$\mathrm{b}_{w R_{2}}=\left\{\sum\left[w\left(F_{\mathrm{o}}^{2}-F_{\mathrm{c}}^{2}\right)^{2}\right] / \sum\left[w\left(F_{\mathrm{o}}^{2}\right)^{2}\right]\right\}^{1 / 2}$

TABLe 2: Selected dond lengths $(\AA)$ and angles $\left({ }^{\circ}\right)$ for $\mathbf{1} \cdot\left(\right.$ py) $\mathrm{C}(\mathrm{Me}) \mathrm{NOH}^{\mathrm{a}}{ }^{\mathrm{a}}$

\begin{tabular}{lccc}
\hline $\mathrm{Mn}-\mathrm{O} 31$ & $2.089(2)$ & $\mathrm{Mn}-\mathrm{N} 2$ & $2.287(3)$ \\
\hline $\mathrm{Mn}-\mathrm{O} 32^{\prime}$ & $2.102(3)$ & $\mathrm{Mn}-\mathrm{N} 11$ & $2.300(3)$ \\
$\mathrm{Mn}-\mathrm{N} 1$ & $2.287(3)$ & $\mathrm{Mn}-\mathrm{N} 12$ & $2.283(3)$ \\
O31-Mn-O32' & $101.06(11)$ & $\mathrm{O} 32^{\prime}-\mathrm{Mn}-\mathrm{N} 12$ & $94.84(11)$ \\
O31-Mn-N1 & $164.21(11)$ & $\mathrm{N} 1-\mathrm{Mn}-\mathrm{N} 2$ & $70.11(10)$ \\
O31-Mn-N2 & $95.50(11)$ & $\mathrm{N} 1-\mathrm{Mn}-\mathrm{N} 11$ & $88.37(10)$ \\
O31-Mn-N11 & $87.21(10)$ & $\mathrm{N} 1-\mathrm{Mn}-\mathrm{N} 12$ & $94.52(10)$ \\
O31-Mn-N12 & $98.23(10)$ & $\mathrm{N} 2-\mathrm{Mn}-\mathrm{N} 11$ & $97.89(10)$ \\
O32'-Mn-N1 & $87.06(11)$ & $\mathrm{N} 2-\mathrm{Mn}-\mathrm{N} 12$ & $161.24(10)$ \\
O32'-Mn-N2 & $95.00(11)$ & $\mathrm{N} 11-\mathrm{Mn}-\mathrm{N} 12$ & $70.19(10)$ \\
O32'-Mn-N11 & $163.96(11)$ & & \\
\hline
\end{tabular}

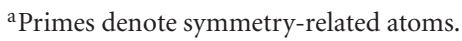

Complex 2 crystallizes in the monoclinic space group $\mathrm{P} 2_{1} / \mathrm{n}$ and its structure consists of mononuclear $\left[\mathrm{Mn}\left(\mathrm{HCO}_{2}\right)_{2}\{(\mathrm{py}) \mathrm{C}(\mathrm{Me}) \mathrm{NOH}\}_{2}\right]$ molecules. Two bidentate chelating (py) $\mathrm{C}(\mathrm{Me}) \mathrm{NOH}$ molecules (1.011 [26], see Scheme 2) and two monodentate $\mathrm{HCO}_{2}{ }^{-}$ions create sixcoordination at the $\mathrm{Mn}^{\mathrm{II}}$ ion. The coordination geometry of the metal ion is distorted octahedral. As $1 \cdot($ py $) \mathrm{C}(\mathrm{Me}) \mathrm{NOH}$, complex 2 is the cis-cis-trans isomer considering the positions of the coordinated $\mathrm{HCO}_{2}{ }^{-}$oxygen, pyridyl nitrogen and oxime nitrogen atoms, respectively.

Intramolecular hydrogen bonds are present in the structure of 2 (Table 5). The oximic oxygen atom of each (py) $\mathrm{C}(\mathrm{Me}) \mathrm{NOH}$ ligand is very strongly intramolecularly hydrogen bonded to one uncoordinated formate oxygen atom.
Complexes $\mathbf{1} \cdot($ py) $\mathrm{C}(\mathrm{Me}) \mathrm{NOH}$ and 2 join a small but growing family of structurally characterized metal complexes containing the neutral or anionic forms of methyl(2pyridyl)ketone oxime as ligands. The 1.011 ligation mode is the exclusive one for the metal complexes containing the neutral ligand $[22,24,30]$.

The structurally characterized $M n$ complexes of (py) $\mathrm{C}(\mathrm{Me}) \mathrm{NOH}$ and/or (py) $\mathrm{C}(\mathrm{Me}) \mathrm{NO}^{-} \quad[14,31-33]$ are collected in Table 6, together with the cores of the polynuclear complexes and the ligands' coordination modes for convenient comparison. Closer inspection of Table 6 reveals that compound $\mathbf{1}$ is the first member of this subfamily in which the $\mathrm{Mn}^{\mathrm{II}}$ ions are linked by the $\mathrm{SO}_{4}{ }^{2-}$ ion. Complex 2 can be compared with the compound $\left[\mathrm{Mn}^{\mathrm{II}}\left(\mathrm{O}_{2} \mathrm{CPh}\right)_{2}\{(\mathrm{py}) \mathrm{C}(\mathrm{Me}) \mathrm{NOH}\}_{2}\right]$ [33] which 
TABle 3: Dimensions of the hydrogen bonds in complex $\mathbf{1} \cdot($ py $) \mathrm{C}(\mathrm{Me}) \mathrm{NOH}{ }^{\mathrm{a}}$

\begin{tabular}{lcccc}
\hline $\mathrm{D}-\mathrm{H} \cdots \mathrm{A}$ & $\mathrm{D} \cdots \mathrm{A}$ & $\mathrm{H} \cdots \mathrm{A}$ & $\mathrm{D}-\mathrm{H} \cdots \mathrm{A}$ & Symmetry Operator of A \\
\hline & {$[\AA]$} & {$[\AA]$} & {$\left[{ }^{\circ}\right]$} & \\
\hline $\mathrm{O}(1)-\mathrm{H}(\mathrm{O} 1) \cdots \mathrm{O}(33)$ & 2.644 & 1.967 & 154.5 & $x, y, z$ \\
$\mathrm{O}\left(11^{\prime}\right)-\mathrm{H}\left(\mathrm{O} 11^{\prime}\right) \cdots \mathrm{O}(33)$ & 2.598 & 1.720 & 174.8 & $x, y, z$ \\
\hline
\end{tabular}

${ }^{\mathbf{a}} \mathrm{A}=$ acceptor, $\mathrm{D}=$ donor.

TABLE 4: Selected dond lengths $(\AA)$ and angles $\left(^{\circ}\right)$ for 2.

\begin{tabular}{lccc}
\hline Mn-O3 & $2.125(1)$ & $\mathrm{Mn}-\mathrm{N} 2$ & $2.248(1)$ \\
\hline $\mathrm{Mn}-\mathrm{O} 5$ & $2.091(1)$ & $\mathrm{Mn}-\mathrm{N} 3$ & $2.305(1)$ \\
$\mathrm{Mn}-\mathrm{N} 1$ & $2.272(1)$ & $\mathrm{Mn}-\mathrm{N} 4$ & $2.264(1)$ \\
O3-Mn-O5 & $95.48(5)$ & $\mathrm{O}-\mathrm{Mn}-\mathrm{N} 4$ & $95.61(4)$ \\
O3-Mn-N1 & $87.76(5)$ & $\mathrm{N} 1-\mathrm{Mn}-\mathrm{N} 2$ & $70.98(4)$ \\
O3-Mn-N2 & $94.27(5)$ & $\mathrm{N} 1-\mathrm{Mn}-\mathrm{N} 4$ & $89.65(5)$ \\
O3-Mn-N3 & $172.60(5)$ & $\mathrm{N} 2-\mathrm{Mn}-\mathrm{N} 3$ & $90.78(5)$ \\
O3-Mn-N4 & $102.46(5)$ & $\mathrm{N} 2-\mathrm{Mn}-\mathrm{N} 4$ & $91.43(5)$ \\
O5-Mn-N1 & $172.03(5)$ & $\mathrm{N} 3-\mathrm{Mn}-\mathrm{N} 4$ & $154.80(5)$ \\
O5-Mn-N2 & $101.47(5)$ & & $70.64(5)$ \\
O5-Mn-N3 & $87.99(4)$ & & \\
\hline
\end{tabular}

TABle 5: Dimensions of the hydrogen bonds in complex $2 .^{\text {a }}$

\begin{tabular}{lcccc}
\hline $\mathrm{D}-\mathrm{H} \cdots \mathrm{A}$ & $\mathrm{D} \cdots \mathrm{A}$ & $\mathrm{H} \cdots \mathrm{A}$ & $\mathrm{D}-\mathrm{H} \cdots \mathrm{A}$ & Symmetry Operator of A \\
\hline $\mathrm{O}(1)-\mathrm{H}(\mathrm{O} 1) \cdots \mathrm{O}(6)$ & {$[\AA]$} & {$[\AA]$} & {$\left[{ }^{\circ}\right]$} & 167.2 \\
$\mathrm{O}(2)-\mathrm{H}(\mathrm{O} 2) \cdots \mathrm{O}(4)$ & 2.542 & 1.710 & 165.4 & $x, y, z$ \\
\end{tabular}

${ }^{\mathrm{a}} \mathrm{A}=$ acceptor, $\mathrm{D}=$ donor.

TABLE 6: Formulae, coordination modes of the ligands, and cores of the structurally characterized Mn complexes of (py)C(Me)NOH and/or (py) $\mathrm{C}(\mathrm{Me}) \mathrm{NO}^{-}$.

\begin{tabular}{|c|c|c|c|}
\hline Complex ${ }^{\mathrm{a}}$ & $\begin{array}{l}\text { Coordination } \\
\text { modes }^{\mathrm{b}}\end{array}$ & Core $^{\mathrm{c}}$ & Ref. \\
\hline$\left[\mathrm{Mn}_{3} \mathrm{III}_{3} \mathrm{O}\left(\mathrm{O}_{2} \mathrm{CMe}\right)_{3}\left\{(\text { py }) \mathrm{C}(\mathrm{Me}) \mathrm{NO}_{3}\right]^{+}\right.$ & 2.111 & {$\left[\mathrm{Mn}_{3}\left(\mu_{3}-\mathrm{O}\right)\right]^{7+}$} & {$[14]$} \\
\hline$\left[\mathrm{Mn}_{3}^{\mathrm{III}} \mathrm{O}\left(\mathrm{O}_{2} \mathrm{CEt}\right)_{3}\{(\mathrm{py}) \mathrm{C}(\mathrm{Me}) \mathrm{NO}\}_{3}\right]^{+}$ & 2.111 & {$\left[\mathrm{Mn}_{3}\left(\mu_{3}-\mathrm{O}\right)\right]^{7+}$} & {$[14]$} \\
\hline$\left[\mathrm{Mn}^{\mathrm{III}} \mathrm{Cl}_{2}\{(\mathrm{py}) \mathrm{C}(\mathrm{Me}) \mathrm{NO}\}\{(\mathrm{py}) \mathrm{C}(\mathrm{Me}) \mathrm{NOH}\}_{2}\right]$ & 1.011 & & {$[32]$} \\
\hline$\left[\mathrm{Mn}^{\mathrm{II}}\left(\mathrm{O}_{2} \mathrm{CPh}\right)_{2}\{(\mathrm{py}) \mathrm{C}(\mathrm{Me}) \mathrm{NOH}\}_{2}\right]$ & 1.011 & & {$[33]$} \\
\hline$\left[\mathrm{Mn}_{4}^{\mathrm{II}} \mathrm{Mn}_{4}^{\mathrm{III}} \mathrm{O}_{2}(\mathrm{OH})_{2}\left(\mathrm{O}_{2} \mathrm{CPh}\right)_{10}\{(\mathrm{py}) \mathrm{C}(\mathrm{Me}) \mathrm{NO}\}_{4}\right]$ & 2.111 & {$\left[\mathrm{Mn}_{8}\left(\mu_{4}-\mathrm{O}\right)_{2}\left(\mu_{3}-\mathrm{OH}\right)_{2}\right]^{14+}$} & {$[33]$} \\
\hline$\left[\mathrm{Mn}_{2}^{\mathrm{II}} \mathrm{Mn}^{\mathrm{IV}}(\mathrm{OMe})_{2}\left\{(\mathrm{py}) \mathrm{C}(\mathrm{Me}) \mathrm{NO}_{4} \mathrm{Br}_{2}\right]\right.$ & 2.111 & {$\left[\mathrm{Mn}_{3}\left(\mu_{3}-\mathrm{OMe}\right)_{2}\right]^{6+}$} & [31] \\
\hline$\left[\mathrm{Mn}_{2}{ }_{2}^{\mathrm{II}} \mathrm{Mn}_{6}{ }_{6} \mathrm{O}_{4}(\mathrm{OMe})\{(\mathrm{py}) \mathrm{C}(\mathrm{Me}) \mathrm{NO}\}_{9}\{(\mathrm{py}) \mathrm{C}(\mathrm{Me}) \mathrm{NOH}\}\right]^{4+}$ & $2.111,3.211$ & {$\left[\mathrm{Mn}_{8}\left(\mu_{3}-\mathrm{O}\right)_{4}(\mu-\mathrm{OMe})\left(\mu-\mathrm{OR}^{\prime \prime}\right)\right]^{11+\mathrm{d}}$} & {$[31]$} \\
\hline$\left[\mathrm{Mn}_{2}{ }_{2}\left(\mathrm{SO}_{4}\right)_{2}\{(\mathrm{py}) \mathrm{C}(\mathrm{Me}) \mathrm{NOH}\}_{4}\right]$ & 1.011 & & This work \\
\hline$\left[\mathrm{Mn}^{\mathrm{II}}\left(\mathrm{HCO}_{2}\right)_{2}\{(\mathrm{py}) \mathrm{C}(\mathrm{Me}) \mathrm{NOH}\}_{2}\right]$ & 1.011 & & This work \\
\hline
\end{tabular}

contains terminal $\mathrm{PhCO}_{2}{ }^{-}$ions, instead of $\mathrm{HCO}_{2}{ }^{-}$in 2; the $\mathrm{HCO}_{2}^{-}$versus $\mathrm{PhCO}_{2}{ }^{-}$change has little structural effect.

3.3. IR Spectra. Complexes $\mathbf{1}$ and $\mathbf{2}$ exhibit medium to strong intensity IR bands at $\sim 3400 \mathrm{~cm}^{-1}$, assignable to $\nu(\mathrm{H})$ vibrations of the (py) $\mathrm{C}(\mathrm{Me}) \mathrm{NOH}$ molecules. The broadness and relatively low frequency of these bands are both indicative of hydrogen bonding.

The $v(\mathrm{C}=\mathrm{N})_{\text {oxime }}$ and $v(\mathrm{~N}-\mathrm{O})_{\text {oxime }}$ vibrations for the free ligand appear as medium intensity bands at 1566 and $1116 \mathrm{~cm}^{-1}$, respectively $[34,35]$. The $1116 \mathrm{~cm}^{-1}$ band is shifted to a lower wavenumber in 1 and 2 (1, 1080; 2 , $\left.1042 \mathrm{~cm}^{-1}\right)$. This shift is attributed to the coordination 


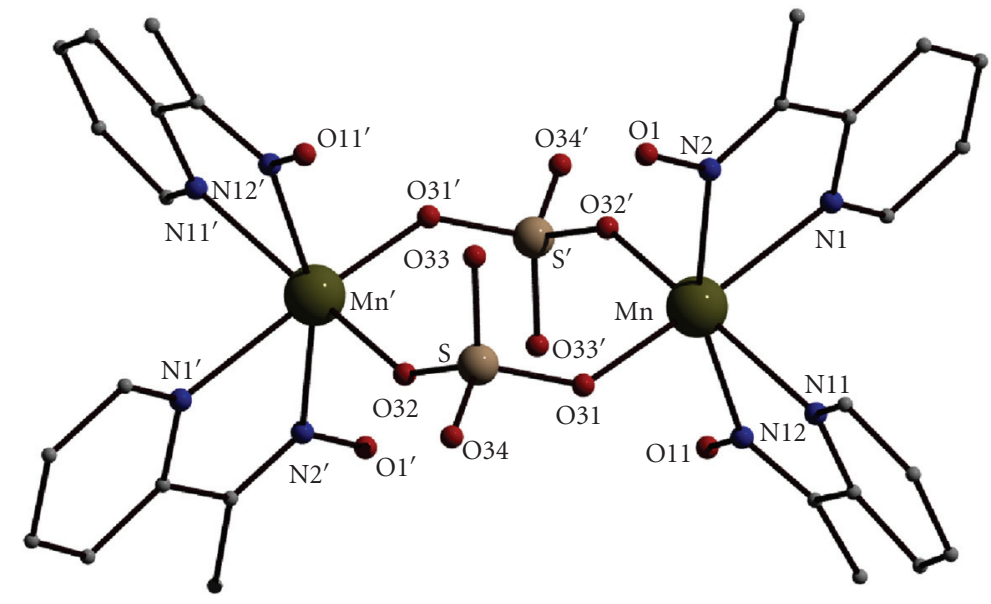

FIgure 1: The dinuclear molecule present in $\mathbf{1} \cdot(\mathrm{py}) \mathrm{C}(\mathrm{Me}) \mathrm{NOH}$. Primes are used for the symmetry-related atoms.

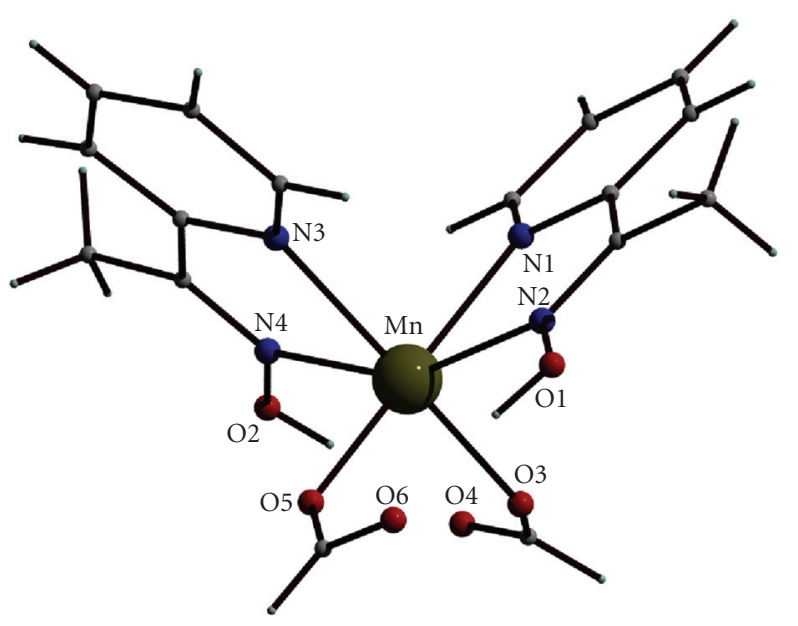

Figure 2: The molecular structure of compound 2.

of the neutral oxime nitrogen [22]. The strong band at $1124 \mathrm{~cm}^{-1}$ in the spectrum of $\mathbf{1} \cdot(\mathrm{py}) \mathrm{C}(\mathrm{Me}) \mathrm{NOH}$ should also have a $\nu(\mathrm{N}-\mathrm{O})_{\text {oxime }}$ character resulting from the presence of lattice (py)C(Me)NOH molecules in the structure. Several bonds appear in the $1655-1400 \mathrm{~cm}^{-1}$ region for both complexes; contribution from the $\nu(\mathrm{C}=\mathrm{N})$ oxime and $\delta(\mathrm{OH})$ modes $\left(>1580 \mathrm{~cm}^{-1}\right)$ are expected in this region, but overlap with the stretching vibrations of the aromatic rings and the carboxylate groups (for 2) renders assignments and discussion of the coordination shifts difficult.

The in-plane deformation band of the 2-pyridyl ring of free (py)C(Me)NOH at $637 \mathrm{~cm}^{-1}$ shifts upwards in 1 $\left(683 \mathrm{~cm}^{-1}\right)$ and $2\left(683 \mathrm{~cm}^{-1}\right)$, confirming the involvement of the ring- $\mathrm{N}$ atom in coordination [36]. The appearance of a medium intensity band at $631 \mathrm{~cm}^{-1}$ in the spectrum of $1 \cdot($ py $) \mathrm{C}(\mathrm{Me}) \mathrm{NOH}$ is indicative of the presence of lattice (py)C(Me)NOH molecules in this complex.
The IR spectrum of the free, that is, ionic, sulfate (the $\mathrm{SO}_{4}{ }^{2-}$ ion belongs to the $T_{\mathrm{d}}$ point group) consists of two bands at $\sim 1105$ and $\sim 615 \mathrm{~cm}^{-1}$, assigned to the $\nu_{3}\left(F_{2}\right)$ stretching $\left[\nu_{\mathrm{d}}(\mathrm{SO})\right]$ and $\nu_{4}\left(F_{2}\right)$ bending $\left[\delta_{d}(\mathrm{OSO})\right]$ modes, respectively $[27,37,38]$. The $\nu_{1}\left(A_{1}\right)$ stretching $\left[\nu_{s}(\mathrm{SO})\right]$ and $\nu_{2}(E)$ bending $[\delta \mathrm{d}(\mathrm{OSO})]$ modes are not IR-active (these are Raman-active). The coordination of $\mathrm{SO}_{4}{ }^{2-}$ to metal ions decreases the symmetry of the group and the $v_{3}$ and $v_{4}$ modes are split $[27,37,38]$. In the case, the $\mathrm{SO}_{4}{ }^{2-}$-site symmetry is lowered from $T_{\mathrm{d}}$ to $C_{3 \mathrm{v}}$ (monodentate coordination), both $v_{1}$ and $v_{2}$ appear in the IR spectrum with weak to medium intensity, while $v_{3}$ and $v_{4}$ each splits into two bands in both IR and Raman spectra [37]. When the $\mathrm{SO}_{4}{ }^{2-}$-site symmetry is lowered from $T_{\mathrm{d}}$ to $C_{2 \mathrm{v}}$ (bidentate chelating or bridging coordination), again $\nu_{1}$ and $\nu_{2}$ appear in the IR spectrum ( $\nu_{2}$ splits into two Raman modes), while $v_{3}$ and $v_{4}$ each splits into three IR-active and Raman-active vibrations [37]. The crystallographically established symmetry of the sulfato groups in $1 \cdot($ py $) \mathrm{C}(\mathrm{Me}) \mathrm{NOH}$ is $C_{2 \mathrm{v}}$. The bands at 1215,1124 and 1080 (overlapping with the $\mathrm{N}-\mathrm{O}_{\text {oxime }}$ stretch) $\mathrm{cm}^{-1}$ are attributed to the $v_{3}$ modes $[37,39]$, while the bands at 592, 631 and $683 \mathrm{~cm}^{-1}$ (the latter two overlapping with the inplane 2-pyridyl deformations) are assigned to the $v_{4}$ modes $[37,38]$. The band at $1010 \mathrm{~cm}^{-1}$ and the two weak features at 494 and $452 \mathrm{~cm}^{-1}$ can be assigned to the $\nu_{1}$ and $\nu_{2}$ modes, respectively. The appearance of two $\nu_{2}$ bands is consistent with a symmetry at the sulfato groups lower than $C_{2 \mathrm{v}}$ $[37,39]$. Thus, from the vibrational spectroscopy viewpoint, the sulfato ligands of $\mathbf{1} \cdot(\mathrm{py}) \mathrm{C}(\mathrm{Me}) \mathrm{NOH}$ appear to have $C_{\mathrm{i}}$ symmetry (and not $C_{2 \mathrm{v}}$ as deduced from their bidentate character). When the $\mathrm{SO}_{4}{ }^{2-}$-site symmetry is lowered from $T_{\mathrm{d}}$ to $C_{\mathrm{i}}, v_{3}$ and $v_{4}$ each splits into three IR-active vibrations, $v_{2}$ splits into two ones, while $\nu_{1}$ appears as a single band $[37,39]$. This spectroscopic feature in $\mathbf{1} \cdot(\mathrm{py}) \mathrm{C}(\mathrm{Me}) \mathrm{NOH}$ is attributed to the fact that one uncoordinated oxygen atom of each bidentate bridging sulfate is hydrogen bonded to the oxygen atoms of the neutral oxime groups (see Table 3 ) resulting in a further lowering of the sulphate symmetry [39]. 
The $v\left(\mathrm{CO}_{2}\right)$ bands are difficult to assign in the spectrum of 2 due to the appearance of various stretching vibrations in the $1600-1400 \mathrm{~cm}^{-1}$ region and thus the application of the spectroscopic criterion of Deacon and Phillips [40] is very difficult.

\section{Conclusions}

The use of the sulfate ligand in combination with neutral (py)C(Me)NOH in $\mathrm{Mn}(\mathrm{II})$ chemistry has provided access to the two new neutral complexes $\left[\mathrm{Mn}_{2}\left(\mathrm{SO}_{4}\right)_{2}\{(\mathrm{py}) \mathrm{C}(\mathrm{Me}) \mathrm{NOH}\}_{4}\right] \cdot(\mathrm{py}) \mathrm{C}(\mathrm{Me}) \mathrm{NOH}(\mathbf{1}$. (py) $\mathrm{C}(\mathrm{Me}) \mathrm{NOH})$ and $\left[\mathrm{Mn}\left(\mathrm{HCO}_{2}\right)_{2}\{(\mathrm{py}) \mathrm{C}(\mathrm{Me}) \mathrm{NOH}\}_{2}\right]$ (2), the latter being sulphate-free. In both complexes, the organic ligand chelates through its nitrogen atoms. The sulfate anion bridges the two $\mathrm{Mn}^{\mathrm{II}}$ atoms in 1 . Compounds $1 \cdot($ py) $\mathrm{C}(\mathrm{Me}) \mathrm{NOH}$ and 2 join a small family of structurally characterized manganese complexes containing the neutral or anionic forms of methyl(2-pyridyl)ketone oxime as ligands, while they are new examples of structurally characterized compounds in which (py)C(Me) NOH exists exclusively in its neutral form.

Analogues of 1-(py) $\mathrm{C}(\mathrm{Me}) \mathrm{NOH}$ and 2 with phenyl(2pyridyl)ketone oxime, (py) $\mathrm{C}(\mathrm{ph}) \mathrm{NOH}$, are not known to date, and it is currently not evident whether the stability of these species is dependent on the particular nature of the 2-pyridyl oxime ligand. We are studying this matter. Synthetic efforts are also in progress to "activate" the $\mu_{3}$ to $\mu_{6}$ bridging potential of the sulfate ligand in $\mathrm{Mn}$ complexes containing 2-pyridyl oximes and/or their anions as a means to get access to clusters and polymers with interesting structural and magnetic properties. Studies on the biological activity of $\mathbf{1} \cdot(\mathrm{py}) \mathrm{C}(\mathrm{Me}) \mathrm{NOH}$ and $\mathbf{2}$ are also planned.

\section{Supplementary Information}

CCDC 757892 and 757893 contain the supplementary crystallographic data for $\mathbf{1} \cdot(\mathrm{py}) \mathrm{C}(\mathrm{Me}) \mathrm{NOH}$ and $\mathbf{2}$. These data can be obtained free of charge via http://www.ccdc.cam .ac.uk/conts/retrieving.html, or from the Cambridge Crystallographic Data Centre, 12 Union Road, Cambridge CB2 1EZ, UK; fax: (+44)1223-336033; or e-mail: deposit@ccdc deposit@ccdc.cam.ac.uk.

\section{Acknowledgments}

This work was supported by the Cyprus Research Promotion Foundation (Grant DIETHNIS/STOXOS/0308/14). In dedication to Professor Nick Hadjiliadis for his retirement and for his important contributions to Bioinorganic Chemistry.

\section{References}

[1] C. J. Milios, T. C. Stamatatos, and S. P. Perlepes, "The coordination chemistry of pyridyl oximes," Polyhedron, vol. 25, no. 1, pp. 134-194, 2006.
[2] D. T. Rosa, J. A. Krause Baue, and M. J. Baldwin, "Structural and spectroscopic studies of the versatile coordination chemistry of the chiral ligand $N, N$-bis(1-propan-2-onyl oxime)L-methionine $\mathrm{N}^{\prime}$-methylamide with $\mathrm{Ni}^{\mathrm{II}}$ and $\mathrm{Zn}^{\mathrm{II}}$," Inorganic Chemistry, vol. 40, no. 7, pp. 1606-1613, 2001.

[3] K. Sauer, J. Yano, and V. K. Yachandra, "X-ray spectroscopy of the photosynthetic oxygen-evolving complex," Coordination Chemistry Reviews, vol. 252, no. 3-4, pp. 318-335, 2008.

[4] A. Mishra, J. Yano, Y. Pushkar, V. K. Yachandra, K. A. Abboud, and G. Christou, "Heteronuclear $\mathrm{Mn}-\mathrm{Ca} / \mathrm{Sr}$ complexes, and $\mathrm{Ca} / \mathrm{Sr}$ EXAFS spectral comparisons with the Oxygen-Evolving Complex of Photosystem II," Chemical Communications, no. 15, pp. 1538-1540, 2007.

[5] D. Burdinski, F. Birkelbach, T. Weyhermüller et al., "Encapsulation by a chromium(III)-containing bicyclic ligand cage. synthesis, structures, and physical properties of heterometal complexes $\mathrm{Cr}^{I I I} \mathrm{MCr}^{I I I}\left[\mathrm{M}=\left(H^{+}\right)_{2}, \operatorname{Li}(I), \mathrm{Mg}(I I), \mathrm{Cu}(I I)\right.$, $\mathrm{Ni}(I I), \mathrm{Ni}(\mathrm{IV}), \mathrm{Co}(\mathrm{III}), \mathrm{Fe}(\mathrm{II}), \mathrm{Fe}(\mathrm{III}), \mathrm{Mn}(\mathrm{II})]$ ], Inorganic Chemistry, vol. 37, no. 5, pp. 1009-1020, 1998.

[6] V. Yu. Kukushkin and A. J. L. Pombeiro, "Oxime and oximate metal complexes: unconventional synthesis and reactivity," Coordination Chemistry Reviews, vol. 181, no. 1, pp. 147-175, 1999.

[7] M. J. Goldcamp, S. E. Robison, J. A. Krause Bauer, and M. J. Baldwin, "Oxygen reactivity of a nickel(II)-polyoximate complex," Inorganic Chemistry, vol. 41, no. 9, pp. 2307-2309, 2002.

[8] M. N. Kopylovich, V. Yu. Kukushkin, M. Haukka, J. J. R. Fraústo da Silva, and A. J. L. Pombeiro, "Zinc(II)/ketoxime system as a simple and efficient catalyst for hydrolysis of organonitriles," Inorganic Chemistry, vol. 41, no. 18, pp. 47984804, 2002.

[9] S. Akine, T. Taniguchi, T. Saiki, and T. Nabeshima, " $\mathrm{Ca}^{2+}$ and $\mathrm{Ba}^{2+}$-selective receptors based on site-selective transmetalation of multinuclear polyoxime-zinc(II) complexes," Journal of the American Chemical Society, vol. 127, no. 2, pp. 540-541, 2005.

[10] A. J. L. Pombeiro and V. Yu. Kukushkin, "Reactivity of coordinated oximes," in Comprehensive Coordination Chemistry II, J. A. McCleverty and T. J. Meyer, Eds., vol. 1, pp. 631-637, Elsevier, Amsterdam, The Netherlands, 2004.

[11] J. M. Thorpe, R. L. Beddoes, D. Collison et al., "Surface coordination chemistry: corrosion inhibition by tetranuclear cluster formation of iron with salicylaldoxime," Angewandte Chemie: International Edition, vol. 38, no. 8, pp. 1119-1121, 1999.

[12] S. Khanra, T. Weyhermüller, E. Bill, and P. Chaudhuri, "Deliberate synthesis for magnetostructural study of linear tetranuclear complexes $B^{I I I} M n^{I I} M n^{I I} B^{I I I}$, $M n^{I I I} M n^{I I} M n^{I I} M n^{I I I}, M n^{I V} M n^{I I} M n^{I I} M n^{I V}$, $\mathrm{Fe}^{I I I} \mathrm{Mn} n^{I I} \mathrm{Mn}^{I I} \mathrm{Fe}^{I I I} \mathrm{Cr}^{I I I} \mathrm{Mn}^{I I} \mathrm{Mn}{ }^{I I} \mathrm{Cr}^{I I I}$. Influence of terminal ions on the exchange coupling," Inorganic Chemistry, vol. 45, no. 15, pp. 5911-5923, 2006.

[13] D. Robertson, J. F. Cannon, and N. Gerasimchuk, "Doublestranded metal-organic networks for one-dimensional mixed valence coordination polymers," Inorganic Chemistry, vol. 44, no. 23, pp. 8326-8342, 2005.

[14] T. C. Stamatatos, D. Foguet-Albiol, C. C. Stoumpos et al., "Initial example of a triangular single-molecule magnet from ligand-induced structural distortion of a $\left[\mathrm{Mn}_{3}^{\mathrm{III}} \mathrm{O}\right]^{7+}$ complex," Journal of the American Chemical Society, vol. 127, no. 44, pp. 15380-15381, 2005. 
[15] C. J. Milios, C. P. Raptopoulou, A. Terzis et al., "Hexanuclear manganese(III) single-molecule magnets," Angewandte Chemie: International Edition, vol. 43, no. 2, pp. 210-212, 2003.

[16] C. J. Milios, A. Vinslava, A. G. Whittaker et al., "Microwaveassisted synthesis of a hexanuclear $\mathrm{Mn}^{\mathrm{III}}$ single-molecule magnet," Inorganic Chemistry, vol. 45, no. 14, pp. 5272-5274, 2006.

[17] H. Miyasaka, R. Clérac, K. Mizushima et al., " $\left.\left[\mathrm{Mn}_{2} \text { (saltmen }\right)_{2} \mathrm{Ni}(\text { pao })_{2}(\mathrm{~L})_{2}\right](\mathrm{A})_{2}$ with $\mathrm{L}=$ pyridine, 4-picoline, 4-tert-butylpyridine, $\mathrm{N}$-methylimidazole and $\mathrm{A}=\mathrm{ClO}_{4}^{-}, \mathrm{BF}_{4}^{-}, \mathrm{PF}_{6}^{-}, \mathrm{ReO}_{4}^{-}$: a family of single-chain magnets," Inorganic Chemistry, vol. 42, no. 25, pp. 8203-8213, 2003.

[18] E. Abele, R. Abele, and E. Lukevics, "Pyridine oximes: synthesis, reactions, and biological activity," Chemistry of Heterocyclic Compounds, vol. 39, no. 7, pp. 825-865, 2003.

[19] M. Alexiou, I. Tsivikas, C. Dendrinou-Samara et al., "High nuclearity nickel compounds with three, four or five metal atoms showing antibacterial activity," Journal of Inorganic Biochemistry, vol. 93, no. 3-4, pp. 256-264, 2003.

[20] C. Papatriantafyllopoulou, G. E. Kostakis, C. P. Raptopoulou, A. Terzis, S. P. Perlepes, and J. C. Plakatouras, "Investigation of the $\mathrm{MSO}_{4} \cdot \mathrm{xH}_{2} \mathrm{O}(\mathrm{M}=\mathrm{Zn}, \mathrm{x}=7 ; \mathrm{M}=\mathrm{Cd}, \mathrm{x}=$ 8/3)/methyl 2-pyridyl ketone oxime reaction systemml: a novel Cd(II) coordination polymer versus mononuclear and dinuclear $\mathrm{Zn}$ (II) complexes," Inorganica Chimica Acta, vol. 362, no. 7, pp. 2361-2370, 2009.

[21] C. J. Milios, P. Kyritsis, C. P. Raptopoulou et al., "Di-2-pyridyl ketone oxime $[(\mathrm{py}) 2 \mathrm{CNOH}]$ in manganese carboxylate chemistry: mononuclear, dinuclear and tetranuclear complexes, and partial transformation of (py) ${ }_{2} \mathrm{CNOH}$ to the gem-diolate $(2-)$ derivative of di-2-pyridyl ketone leading to the formation of $\mathrm{NO}_{3}^{-}$," Dalton Transactions, no. 3, pp. 501-511, 2005.

[22] C. Papatriantafyllopoulou, C. P. Raptopoulou, A. Terzis, E. Manessi-Zoupa, and S. P. Perlepes, "Investigation of the zinc chloride/methyl(2-pyridyl)ketone oxime reaction systemml: a mononuclear complex and an inverse 12-metallacrown-4 cluster," Zeitschrift für Naturforschung, vol. 61, no. 1, pp. 3746, 2006.

[23] M. Alexiou, C. Dendrinou-Samara, C. P. Raptopoulou, A. Terzis, and D. P. Kessissoglou, "From monomer zinc-oxamato complexes to tetranuclear inverse 12-membered and octanuclear 12-membered metallacrowns," Inorganic Chemistry, vol. 41, no. 18, pp. 4732-4738, 2002.

[24] K. Riggle, T. Lynde-Kernell, and E. O. Schlemper, "Synthesis and X-ray structures of $\mathrm{Ni}(\mathrm{II})$ complexes of 1-(2pyridinyl)ethanone oxime," Journal of Coordination Chemistry Chemistry, vol. 25, pp. 117-125, 1992.

[25] R. Cibulka, I. Císařová, J. Ondráček, F. Liška, and J. Ludvík, "Electrochemical reductions of $\mathrm{Ni}^{2+}, \mathrm{Cu}^{2+}$ and $\mathrm{Zn}^{2+}$ complexes of azinyl methyl ketoximes on mercury," Collection of Czechoslovak Chemical Communications, vol. 66, no. 1, pp. 170-184, 2001.

[26] R. A. Coxall, S. G. Harris, D. K. Henderson, S. Parsons, P. A. Tasker, and R. E. P. Winpenny, "Inter-ligand reactions: in situ formation of new polydentate ligands," Journal of the Chemical Society, Dalton Transactions, no. 14, pp. 2349-2356, 2000.

[27] C. Papatriantafyllopoulou, E. Manessi-Zoupa, A. Escuer, and S. P. Perlepes, "The sulfate ligand as a promising 'player' in $3 \mathrm{~d}-$ metal cluster chemistry," Inorganica Chimica Acta, vol. 362, no. 3, pp. 634-650, 2009.

[28] S. Y. Nurova, E. P. Turevskaya, V. G. Kessler, and M. I. Yanovskaya, The Chemistry of Metal Alkoxides, Kluwer Academic Publishers, Dordrecht, The Netherlands, 2002.
[29] C. Papatriantafyllopoulou, A. Tasiopoulos, and S. P. Perlepes, unpublished results.

[30] C. Papatriantafyllopoulou, C. P. Raptopoulou, A. Terzis, J. F. Janssens, S. P. Perlepes, and E. Manessi-Zoupa, "Reactions of nickel(II) sulfate hexahydrate with methyl(2-pyridyl)ketone oxime: two mononuclear sulfato complexes containing the neutral ligand," Zeitschrift für Naturforschung, vol. 62, no. 9, pp. 1123-1132, 2007.

[31] C. C. Stoumpos, T. C. Stamatatos, H. Sartzi et al., "Employment of methyl 2-pyridyl ketone oxime in manganese noncarboxylate chemistry: $\mathrm{Mn}_{2}^{\text {II }} \mathrm{Mn}^{\text {IV }}$ and $\mathrm{Mn}_{2}^{\text {II }} \mathrm{Mn}_{6}^{\text {III }}$ complexes," Dalton Transactions, no. 6, pp. 1004-1015, 2009.

[32] J. Zuo, J. Dou, D. Li, D. Wang, and Y. Sun, "Dichlorido[1-(2-pyrid-yl)ethanone oximato][1-(2-pyridyl)ethanone oxime]manganese(III)," Acta Crystallographica E, vol. 63, no. 12, pp. m3183-m3184, 2007.

[33] C. C. Stoumpos, T. C. Stamatatos, V. Psycharis, C. P. Raptopoulou, G. Christou, and S. P. Perlepes, "A new $\mathrm{Mn}_{4}^{\mathrm{II}} \mathrm{Mn}_{4}^{\mathrm{III}}$ cluster from the use of methyl 2-pyridyl ketone oxime in manganese carboxylate chemistry: synthetic, structural and magnetic studies," Polyhedron, vol. 27, no. 18, pp. 3703-3709, 2008.

[34] C. Papatriantafyllopoulou, G. Aromi, A. J. Tasiopoulos et al., "Use of the sulfato ligand in 3d-metal cluster chemistry: a family of hexanuclear nickel(II) complexes with 2-pyridylsubstituted oxime ligands," European Journal of Inorganic Chemistry, no. 18, pp. 2761-2774, 2007.

[35] P. Chaudhuri, M. Winter, U. Flörke, and H.-J. Haupt, "An effectively diamagnetic oximato-bridged asymmetric dinuclear copper(II) complex with a $\mathrm{Cu}(\mathrm{II}) \mathrm{I}$ bond," Inorganica Chimica Acta, vol. 232, no. 1-2, pp. 125-130, 1995.

[36] A. B. P. Lever and E. Mantovani, "The far-infrared and electronic spectra of some bis-ethylenediamine and related complexes of copper(II) and the relevance of these data to tetragonal distortion and bond strengths," Inorganic Chemistry, vol. 10, no. 4, pp. 817-826, 1971.

[37] K. Nakamoto, Infrared and Raman Spectra of Inorganic and Coordination Compounds, Wiley, New York, NY, USA, 4th edition, 1986.

[38] C. Papatriantafyllopoulou, C. G. Efthymiou, C. P. Raptopoulou et al., "Initial use of the di-2-pyridyl ketone/sulfate 'blend' in 3d-metal cluster chemistry: preparation, X-ray structures and physical studies of zinc(II) and nickel(II) cubanes," Journal of Molecular Structure, vol. 829, no. 1-3, pp. 176-188, 2007.

[39] C. Papatriantafyllopoulou, C. G. Efthymiou, C. P. Raptopoulou, A. Terzis, E. Manessi-Zoupa, and S. P. Perlepes, "Mononuclear versus dinuclear complex formation in nickel(II) sulfate/phenyl(2-pyridyl)ketone oxime chemistry depending on the ligand to metal reaction ratio: synthetic, spectral and structural studies," Spectrochimica Acta A, vol. 70, no. 4, pp. 718-728, 2008.

[40] G. B. Deacon and R. J. Phillips, "Relationships between the carbon-oxygen stretching frequencies of carboxylato complexes and the type of carboxylate coordination," Coordination Chemistry Reviews, vol. 33, pp. 227-250, 1980. 


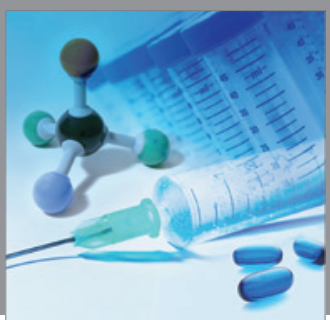

International Journal of

Medicinal Chemistry

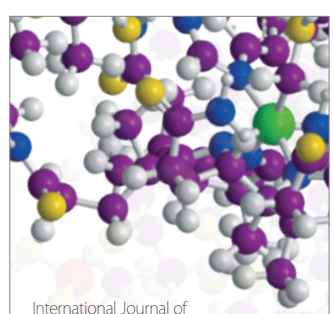

Carbohydrate Chemistry

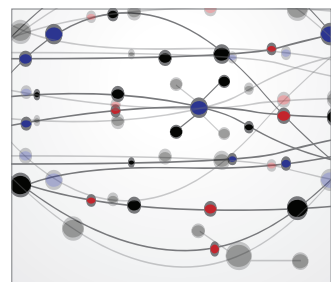

The Scientific World Journal
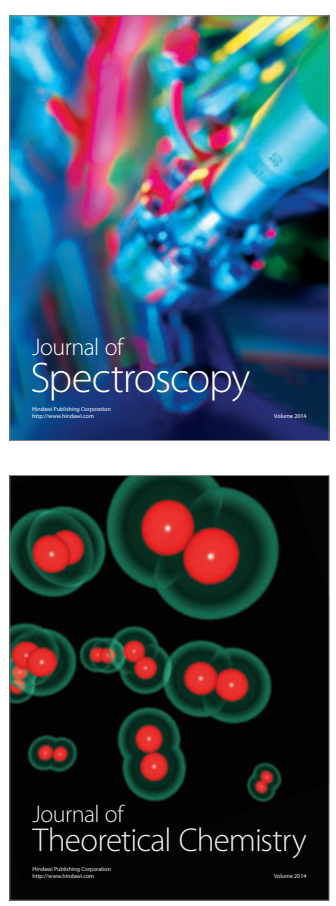
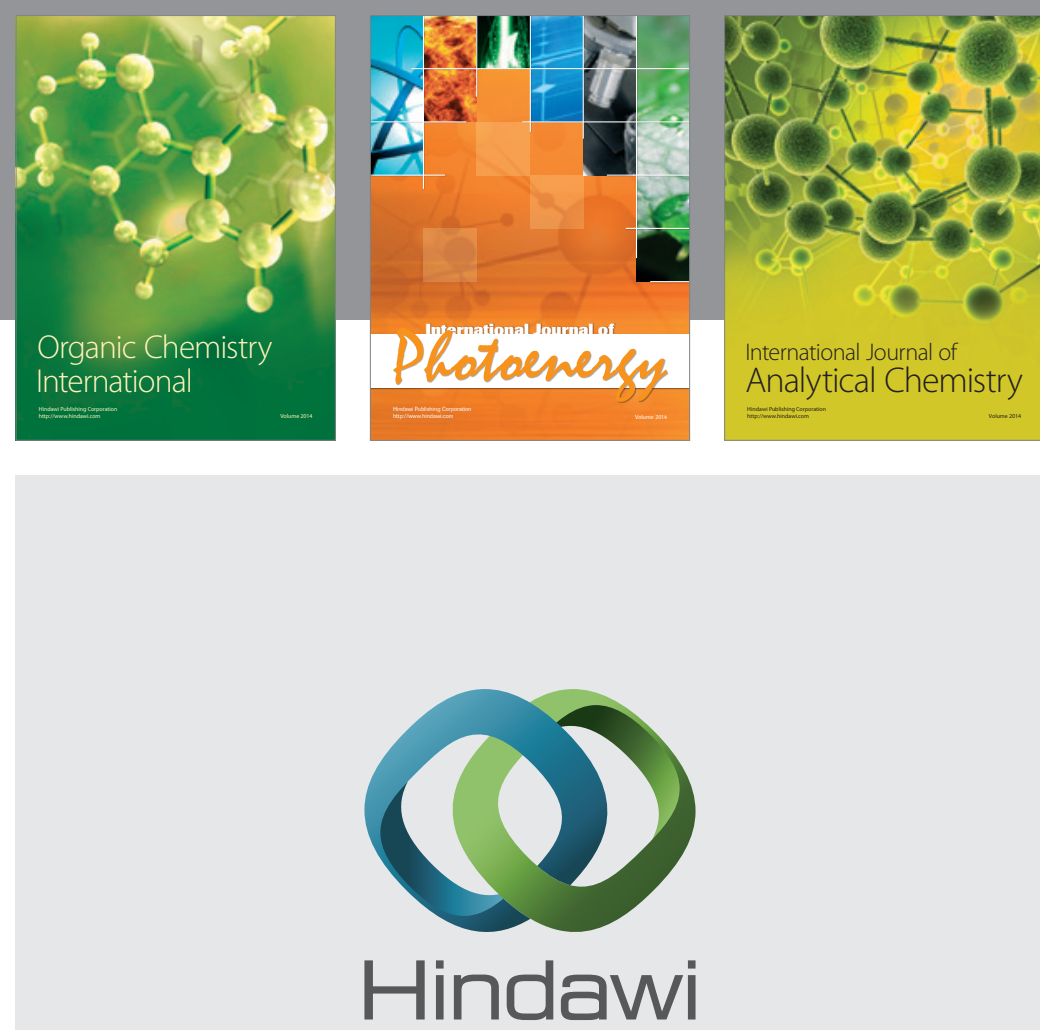

Submit your manuscripts at

http://www.hindawi.com
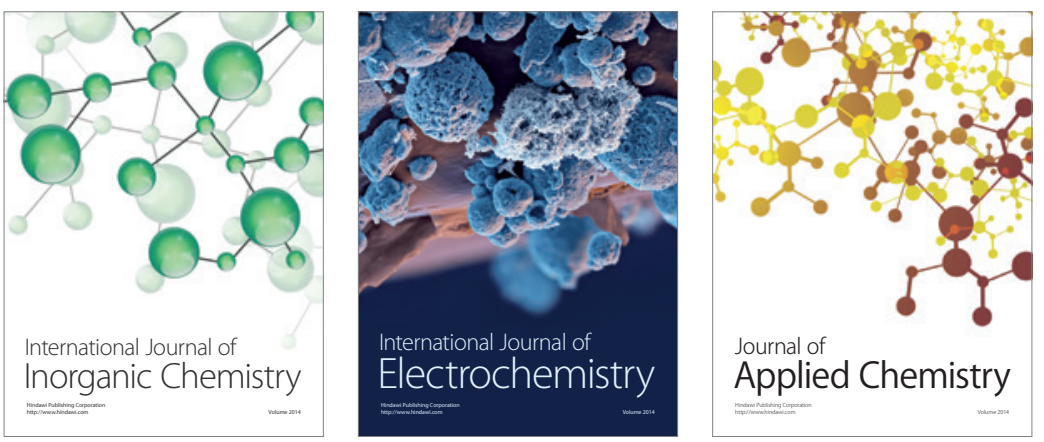

Journal of

Applied Chemistry
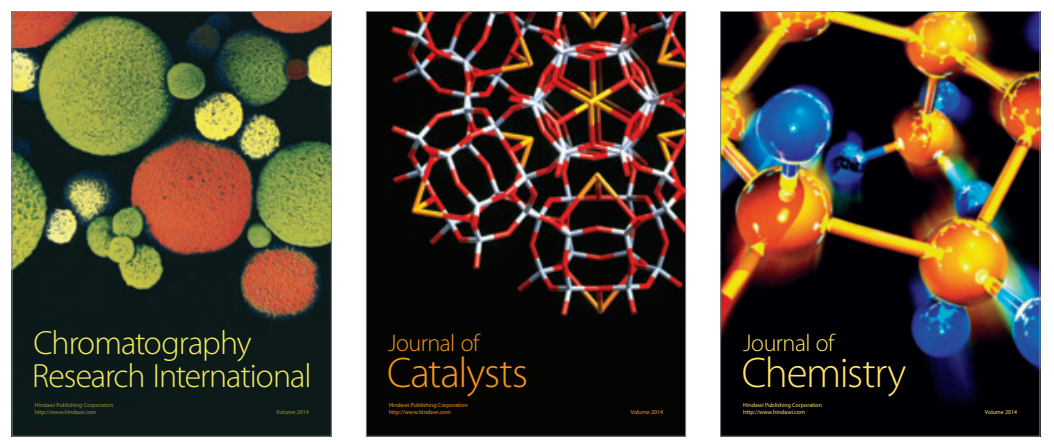
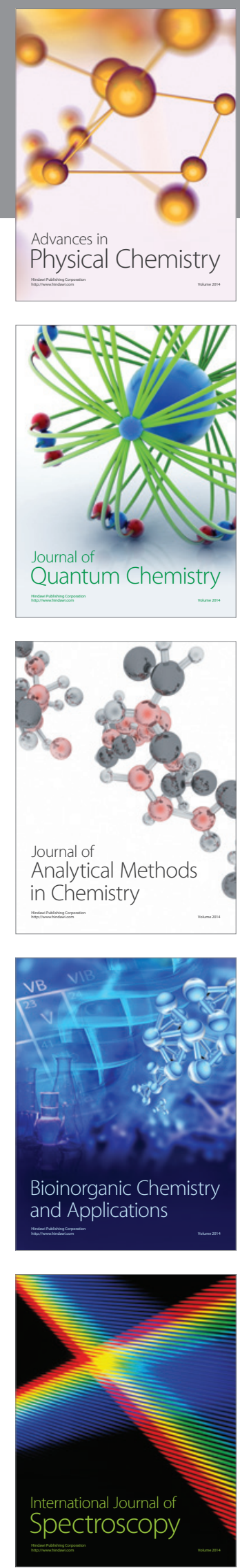